JOURNAL

OF URBAN

SOCIETY'S ARTS

Volume 5 Nomor 2,

Oktober 2018: 66-73

\title{
Mendobrak Kriteria Perempuan sebagai Model Fesyen dalam Indonesia Plus-Size Festival 2018
}

\section{Bonifacia Bulan Arumingtyas}

Program Studi Pengkajian Seni Pertunjukan dan Seni Rupa, Sekolah Pascasarjana

Universitas Gadjah Mada Yogyakarta

Jl. Teknika Utara, Pogung, Sleman, Yogyakarta 55281

Tlp. 082140628406, E-mail: bonnifacia.boelan@gmail.com

\begin{abstract}
ABSTRAK
Sebagai seorang model fesyen, perempuan dituntut untuk memiliki tubuh ideal atau kurus proporsional. Seringnya menampilkan tubuh kurus perempuan, menjadikan sebuah konstruksi tentang standar kecantikan perempuan. Konstruksi tersebut menyebabkan sosok perempuan yang tidak bertubuh ideal atau gemuk, tidak layak tampil di muka publik. Berbeda dengan Indonesia Plus Size Festival 2018 yang digagas oleh Ririe Bogar. Ririe Bogar justru melakukan audisi model khusus untuk perempuan gemuk dengan berat minimal $70 \mathrm{~kg}$. Penelitian ini menerapkan metode fenomenologis yang melibatkan langsung peneliti sebagai peserta audisi model untuk melihat fenomena riil yang ada. Selain melihat interaksi sesama perempuan gemuk dalam acara tersebut, peneliti dapat juga melihat respon masyarakat ketika melihat model catwalk yang tidak seperti umumnya, dalam kasus ini bertubuh gemuk. Penelitian ini menunjukkan bahwa tubuh yang gemuk dapat juga dengan baik menampilkan produk fesyen, sedikit demi sedikit, dapat merubah pandangan masyarakat tentang konstruksi standar kecantikan yang selama ini dibentuk.
\end{abstract}

Kata kunci: model fesyen; perempuan gemuk; standar kecantikan

\begin{abstract}
Breaking the Criteria of Women as Fashion Models in Indonesia Plus Size Festival 2018. As a fashion model, women are often required to have ideal or slim and proportional body. This requirement build a certain beauty standard over time which often made overweighted women with non-ideal body type deemed not aesthetic enough to perform in public event. This paradigm is in great contrast with the Indonesia Plus Size Festival 2018, founded by Ririe Bogar. Ririe Bogar commenced an audition specifically for bigsized women with minimum body weight of 70 kilos. The methodology applied in this research called phenomenological method, directly involving researcher as participant in the audition to witness the real phenomenon. Researcher observed the interaction between big-sized women in the event, as well as the public response with this unique modelling event featuring big-sized women as the main model. The result of this research shows that having a plus-sized body type is not an issue in modelling world, especially with the models performed professionally and beautifully in this event, accentuated the fashion product perfectly; Thus shifting the old paradigm on the obsolete beauty standard.
\end{abstract}

Keywords: fashion model; big-sized woman; beauty standard

\section{Pendahuluan}

Perempuan dengan tubuh kurus dan tinggi proporsional kerap ditampilkan sebagai model dalam produk fesyen yang dimuat dalam berbagai media. Model perempuan kurus yang ditampilkan media, pada akhirnya mengkonstruksi ideologi cantik hanya kepada perempuan bertubuh kurus, tetapi tidak pada perempuan bertubuh gemuk (Goenawan, 2007). Disamping konstruksi yang dilakukan oleh media, Naomi Wolf menyebutkan tentang kesadaran perempuan "bahwa sosok 
ideal adalah sosok yang kurus, tinggi, putih, dan berambut pirang, dengan wajah yang mulus tanpa noda, simetri, dan tanpa cacat sedikit pun" (Wolf, 1990). Dalam penulisan buku tersebut, subyek penelitian yang dipilih Wolf adalah pada perempuan Amerika, tetapi hal serupa terjadi juga di Indonesia. Kondisi serupa tersebut terjadi karena media Indonesia juga menampilkan sosok ideal perempuan.

Media secara terus menerus mempertontonkan perempuan bertubuh kurus ideal disamping sebuah produk fesyen. Perilaku media tersebut membentuk pola pikir perempuan gemuk bahwa dirinya tidak mungkin menjadi model pada produk fesyen. Perempuan bertubuh gemuk adalah sosok yang secara lingkungan yang secara kesehatan memiliki kadar BMI yang tinggi.

Berdasarkan situs resmi World Health Organization (WHO), klasifikasi kelebihan berat badan dan obesitas dapat ditentukan dengan pengukuran Body Mass Index (BMI) (WHO, 2017) . WHO menyebutkan rumus pengukuran BMI untuk mengetahui kategori tubuh seorang perempuan dewasa adalah berat badan dalam kilogram dibagi dengan tinggi badan dalam meter persegi. Menghitung tinggi badan dalam meter persegi adalah tinggi badan dalam meter dikali tinggi badan dalam meter. Seperti yang dapat

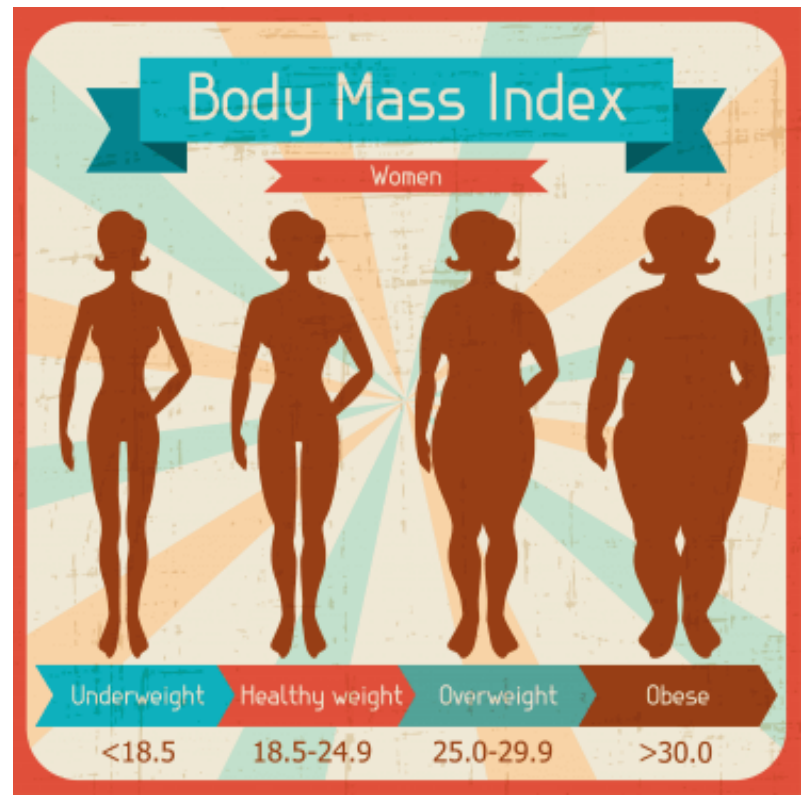

Gambar 1. Pembagian kategori BMI

(Sumber: http://www.weightofthenation.org; diakses pada tanggal 19 Januari 2018) dilihat pada gambar 1, bagi usia dewasa, BMI lebih dari atau sama dengan 25 dikategorikan dalam kelompok overweight atau kelebihan berat badan, sedangkan kelompok obesitas adalah orang-orang dengan angka BMI lebih atau sama dengan 30.

Selain penentuan kadar BMI, perempuan dengan berat badan lebih dari $70 \mathrm{~kg}$ juga dapat dinyatakan sebagai perempuan gemuk, berdasarkan syarat peserta audisi yang ditetapkan oleh Ririe Bogar. Pada tanggal 9 November 2017, Ririe Bogar mengunggah penawaran audisi model pada akun Instagramnya. Audisi model yang ia tawarkan bukan audisi model biasa, namun audisi yang dikhususkan untuk perempuan gemuk yang ingin menjadi model. Jika pada umumnya audisi model mencantumkan syarat tinggi badan dan berat yang proposional, Ririe Bogar justru menampilkan syarat berat minimal para peserta audisi. Ririe mencantumkan angka minimal $70 \mathrm{~kg}$ sebagai berat minimal perempuan yang akan mendaftar audisi tersebut.

Penentuan syarat berat badan yang ditentukan Ririe Bogar, memfokuskan target peserta audisi. Perempuan yang merasa dirinya gemuk dapat juga mendaftar, sekalipun sebenarnya masih tergolong proporsional. Oleh karena itu, Ririe Bogar mencantumkan berat minimal sebagai syarat supaya peserta audisi yang mendaftar benar-benar perempuan gemuk, bukan hanya sekedar merasa tubuhnya gemuk.

Indonesia Plus-Size Festival 2018 - selanjutnya disebut IP-SF 2018, merupakan satu acara dimana para peserta audisi tampil sebagai model. Acara IP-SF 2018 menampilkan peserta audisi menggunakan pakaian yang dihasilkan desainer khusus untuk perempuan gemuk. IP-SF 2018 menampilkan juga perempuan gemuk sebagai penyanyi dan narasumber bincang-bincang, disamping perempuan gemuk sebagai model.

Penelitian ini merumuskan sebuah pertanyaan; bagaimana cara IP-SF 2018 merubah kriteria umum yang dipandang terhadap model fesyen? -pertanyaan tersebut dijawab dengan memaparkan hal-hal yang didapat penulis dari mengikuti acara tersebut. Selain rumusan masalah tersebut, penelitian ini juga bertujuan untuk (a) mengkritisi acara yang melibatkan perempuan gemuk sebagai 
model fesyen; (b) menunjukkan eksistensi perempuan gemuk dalam kehidupan model fesyen.

Dipandang dari perspektif gender, Jeannine A. Gailey menyebutkan bahwa seorang perempuan gemuk secara bersamaan dipandang sebagai sosok yang hyper invisible atau sangat tidak terlihat dan juga hyper visible atau sangat terlihat. Perempuan gemuk disebut sangat tampak secara fisik, tapi dalam perlakuan sosial, perempuan gemuk dianggap tidak ada, salah satunya dalam adanya ketersediaan pakaian siap pakai. Dalam buku yang berjudul The Hyper(in)visible Fat Woman (Gailey, 2014), Gailey memaparkan fenomena tentang hal-hal yang dialami perempuan gemuk. Berbagai aspek kehidupan perempuan gemuk, pada akhirnya dipengaruhi oleh hyper(in)visible. Gailey menyampaikan fokus penelitiannya pada penerimaan konsep hyper(in)visible untuk mendiskusikan tubuh yang termarginal.

Pada dasarnya, fesyen (Kaiser, 2012) merupakan produksi pakaian dan penampilan, yang bekerja melalui proses ide, dan negosiasi posisi subyek pengguna ataupun penciptanya. Di sisi lain, fesyen juga dapat menjadi satu media untuk menyampaikan pesan sosial kepada masyarakat (Tampubolon \& Darmawan, 2016). Fungsi penyampai pesan melalui fesyen, juga dilakukan IP-SF 2018 untuk menunjukkan suatu hal yang masih belum umum terjadi.

Perspektif lain yang dilibatkan dalam penelitian ini adalah perspektif quantum. Persepektif quantum digunakan untuk melihat suatu hal dari aspek fisik dan juga aspek lain diluar fisiknya atau dengan kata lain gelombang yang mengandung makna (Marianto, 2017). Acara IP-FS 2018 yang disusun sedemikian rupa oleh penyelenggara tentu tidak sekedar acara yang berjalan begitu saja, melainkan ada makna-makna yang ditimbulkan dari acara tersebut.

Terlibat langsung untuk mengalami sebagai peserta IP-SF 2018, dapat secara tidak langsung melihat bagaimana perubahan penerimaan masyarakat mengenai konsep perempuan sebagai model fesyen. Metode penelitian fenomenologis (Kahija, 2017) digunakan dalam penelitian ini untuk dapat menunjukkan realitas yang sebenarnya dari suatu fenomena sosial. Disamping melakukan observasi tersebut, peneliti juga melakukan wawancara mendalam dengan Ririe Bogar sebagai penyelenggara IP-SF 2018.

Adanya IP-SF 2018, diharapkan adanya perubahan pandang terhadap perempuan gemuk yang seringkali ditempatkan pada ruang tidak nyaman. IP-SF 2018 juga membangkitkan pola pikir positif perempuan gemuk terhadap penerimaan dirinya dalam masyarakat, bahwa "tubuh yang aktif dan berjiwa keras dalam meraih impian, tidak selalu tergambar pada bentuk tubuh yang ideal" (Prabu, 2017). Pada bagian berikutnya, diberikan pembahasan mengenai jalannya acara IP-SF 2018, serta analisa pada hal-hal dari berbagai sudut pandang dari IP-SF 2018.

\section{Pembahasan \\ Indonesia Plus-Sized Festival 2018}

Fesyen dan perempuan gemuk, merupakan kolaborasi yang dapat ditemukan dalam IP-SF 2018. Tawaran audisi model merupakan langkah awal diadakannya acara IP-SF 2018 seperti yang ada pada gambar 2. Penyelanggara, sekaligus penggagas IP-SF 2018 - Ririe Bogar, mengajak perempuan gemuk dengan minimal berat 70 kilogram untuk mengikuti audisi model. Pada poster penawaran audisi, dituliskan bahwa audisi diadakan pada Januari 2018, untuk partisipasi dalam runway dalam IP-SF 2018.
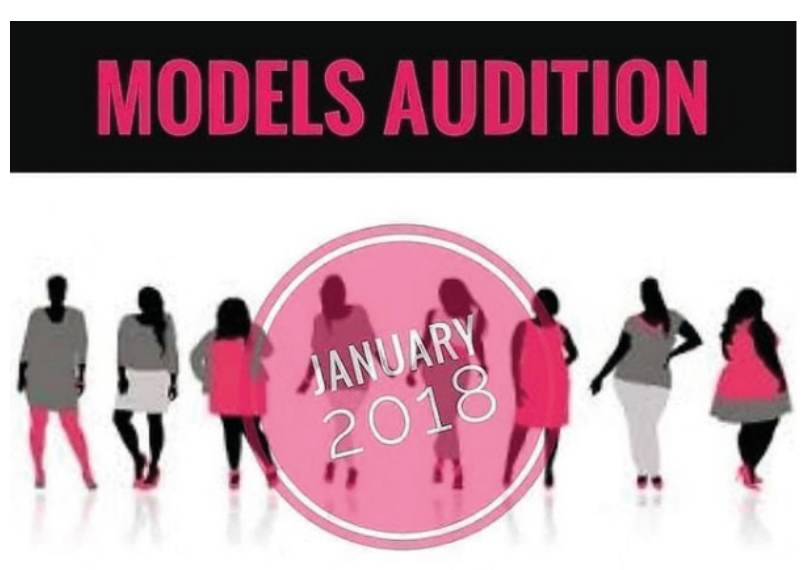

RUNWAY FOR INDONESIA PLUS SIZE FESTIVAL

Gambar 2. Poster ajakan mengikuti audisi model. (Sumber: Akun Instagram Ririe Bogar, www.instagram. com/ririebogar; diakses pada tanggal 19 Januari 2018) 
Ririe Bogar memulai tawaran audisi model pada bulan November 2017. Cara pendaftarannya unik, peserta tidak hanya mengisi formulir seperti pendaftaran pada umumnya. Para calon peserta mendaftar dengan cara mengirimkan e-mail pada Ririe Bogar. E-mail yang dikirimkan para calon peserta, berisi alasan pribadi mengapa ingin menjadi model ukuran besar. Setelah mengirimkan e-mail, Ririe Bogar membalasnya dengan ketentuan mengikuti audisi serta hal lain yang berkaitan dengan audisi tersebut.

Pada balasan e-mail kepada para calon peserta, Ririe Bogar menginformasikan hal-hal yang didapat peserta saat mengikuti audisi, serta kewajiban peserta untuk membayar biaya administrasi sebesar Rp 200.000,-. Dalam audisi model, Ririe Bogar membagi ke dalam lima kelas, meliputi kelas (1) catwalk modeling, (2) padu padan baju, (3) kelas kepribadian, (4) kelas tata rias wajah serta (5) kelas pemotretan. Setelah mengikuti rangkaian audisi, peserta yang lolos mendapatkan kesempatan untuk terlibat dalam runway di acara IP-SF 2018.

Dalam perencanaan, Ririe Bogar menyebutkan bahwa tanggal 14 Januari 2018 merupakan tanggal audisi, berlokasi di Jakarta. Hanya saja, Ririe Bogar tidak menyebutkan secara mendetail megenai tempat acara dan waktu penyelenggaraan audisi, sekedar meminta para calon peserta menunggu informasi hingga satu minggu sebelum audisi diadakan. Ketidak pastian titik lokasi acara audisi dan waktunya, menyulitkan peserta audisi yang dari luar Jakarta, terutama dalam menentukan tempat tinggal sementara. Tiket perjalanan juga tidak bisa ditentukan lebih dulu, mengingat kepastian acara masih belum didapat para peserta.

\section{Audisi Model Big Size}

Audisi model diadakan pada tanggal 14 Januari 2018, berlokasi di gedung Communicasting Academy, Jakarta Selatan. Peserta audisi yang datang tidak hanya berasal dari Jakarta, tetapi juga dari Bandung, Semarang, Yogyakarta, Surabaya, dan Bali. Peserta yang berasal dari luar kota Jakarta cukup merasakan akibat dari ketidak pastian lokasi acara. Lokasi acara baru diinfokan kurang dari 1 minggu sebelum acara diselenggarakan.
Terlepas dari kurangnya informasi lokasi acara dari jauh-jauh hari, waktu acara juga menjadi satu permasalahan. Acara yang dijadwalkan dimulai pada pukul 08.00, mengalami keterlambatan dikarenakan lokasi acara belum dibuka. Keterlambatan membuka tempat acara juga mengakibatkan para perempuan gemuk peserta audisi menunggu di depan lokasi acara yang berupa ruko, tetapi antusias para peserta menoleransi keterlambatan tersebut. Para perempuan gemuk saling berkenalan satu sama lain, penulis sendiri berkenalan dengan peserta yang lainnya. Peserta audisi mayoritas berasal dari Jakarta, mereka terkejut ketika mengetahui penulis datang dari Surabaya.

Antusias peserta makin terlihat saat lokasi acara dibuka, peserta bahkan meluncurkan lelucon menarik seputar audisi, seperti "wah, habis ini bakal ada berita Jakarta Selatan gempa nih, kita gede-gede disini semua", lalu diikuti dengan tawa perempuan lainnya. Menariknya, saat para peserta dikumpulkan dalam satu ruangan, dua orang peserta menawarkan diri untuk membuat kelompok obrolan melalui Whatsapp, yang tidak lama terbentuklah kelompok obrolan tersebut. Selain membentuk kelompok obrolan antar peserta, para peserta yang baru saling mengenal tidak canggung untuk berfoto bersama, seakan telah lama saling mengenal seperti yang dapat dilihat pada gambar 3 .

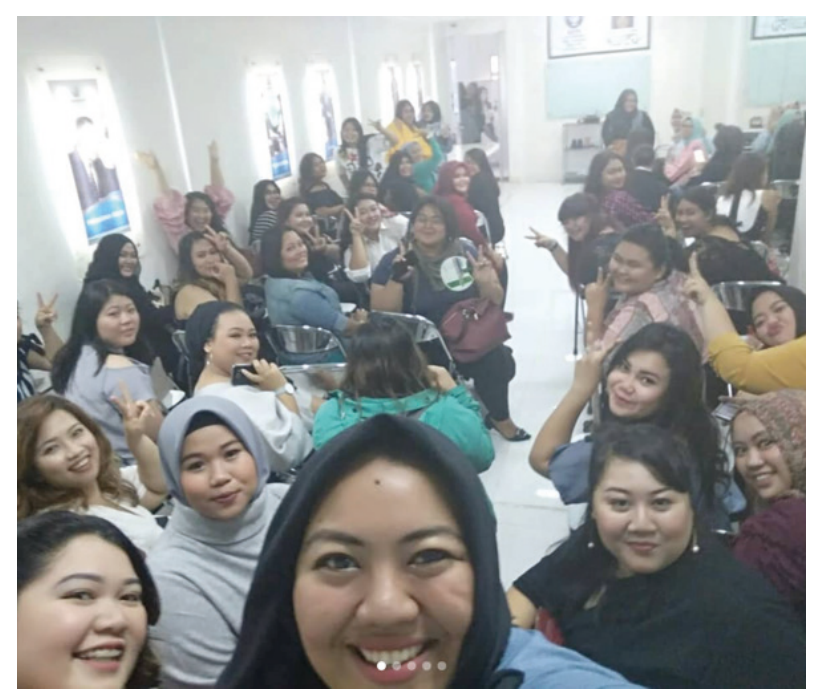

Gambar 3. Swafoto para peserta audisi model. (Sumber: Akun Instagram Niranti Cahyadika, salah seorang peserta audisi model, https:/www.instagram.com/ niranticahyadika/; diakses pada tanggal 15 April 2018) 
Dresscode yang ditentukan oleh panitia audisi adalah "just be yourself", sehingga para peserta datang dengan gaya berpakaian yang beragam. Tidak adanya aturan dari pakaian yang digunakan saat audisi menjadikan peserta datang dengan gaya terbaiknya dan benar-benar menjadi diri sendiri. Penentuan dresscode dari penyelenggara seakan ingin menilai bagaimana para peserta audisi dalam berpenampilan (Arumingtyas, 2018).

Audisi model yang hanya mengakomodasi para perempuan gemuk sebagai pesertanya, menunjukkan beragam perempuan gemuk dengan berbagai gaya berpakaian. Sebagian perempuan gemuk percaya diri walaupun menggunakan pakaian ketaat yang menunjukkan lekuk tubuhnya yang berisi, tetapi sebagian lagi masih sibuk menutupi triple-stomach dari tubuhnya dengan menggunakan pakaian yang longgar.

Penyelenggaraan audisi model dibagi menjadi lima tahap yang menyerupai kelas pembelajaran. Tahap audisi meliputi: (1) kelas berbagi pengalaman dengan model plus size, (2) kelas berjalan di catwalk, (3) kelas pemotretan atau berpose di depan kamera, (4) kelas berbicara di depan umum, dan (5) kelas psikologi. Tahapan audisi pada prakteknya, sedikit berbeda bila dibandingkan dengan yang tertulis pada e-mail penerimaan peserta. Sebelumnya dituliskan bahwa para peserta akan mengikuti kelas padu padan baju dan kelas tata rias wajah, namun kedua kelas tersebut tidak diadakan pada saat audisi. Peniadaan kelas tersebut dapat disebabkan karena banyaknya peserta diluar perkiraan penyelenggara, meskipun pada akhinya membuat kecewa peserta yang membutuhkan kelas tersebut.

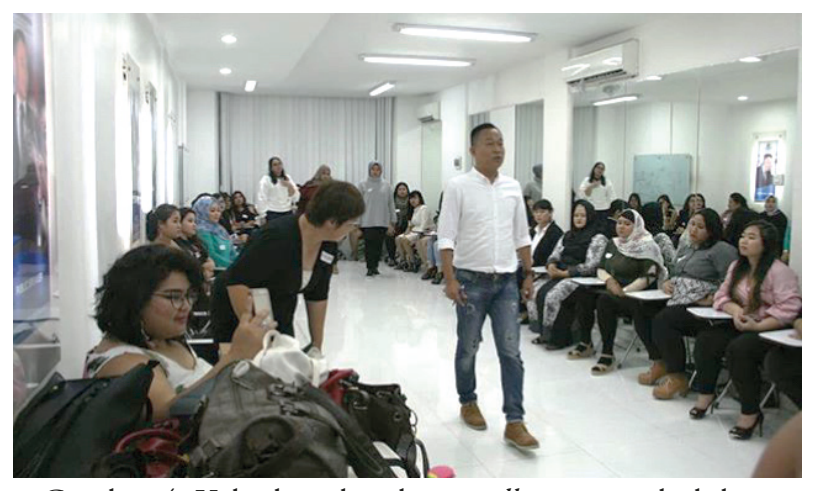

Gambar 4. Kelas berjalan di catwalk yang wajib diikuti seluruh peserta audisi. (Sumber: Akun Instagram acara IP-SF 2018 www.instagram.com/indonesiaplussizefestival; diakses pada tanggal 15 April 2018, pukul 18:57)
Pada pelaksaan audisi, peserta menjadi tiga kelompok, sehingga para peserta tidak secara bersamaan mengikuti kelas dalam audisi. Selain untuk efektifitas waktu, pembagian kelompok tersebut juga bertujuan supaya materi yang disampaikan lebih dapat diterima oleh para peserta. Salah satu suasana kelas dapat dilihat pada gambar 4, yang merupakan kelas berjalan di catwalk. Pada gambar 4, tampak Oditama sebagai mentor saat memberi contoh berjalan ala model bagi para peserta audisi.

Salah satu kelas yang secara teknis tidak berhubungan dengan model fesyen adalah kelas psikilogi. Kelas yang diberikan dengan tes kecil berkaitan dengan diri peserta tentu saja dilakukan untuk mengetahui gambaran karakter setiap peserta. Audisi yang hanya dilakukan satu hari, terlalu singkat untuk mengetahui kepribadian seseorang. Keterbatasan waktu itulah yang pada akhirnya membuat penyelenggara mengadakan kelas psikologi bagi seluruh peserta. Hasil tes tersebut menjadi salah satu faktor kelolosan bagi peserta audisi untuk masuk tahapan berikutnya.

Pada saat penyelenggaraan audisi, ternyata Ririe Bogar masih mendapat pesan dari perempuan gemuk lain yang ingin mengikuti audisi model yang sama, hingga akhirnya diselenggarakan lagi audisi model gelombang kedua. Audisi gelombang kedua diadakan di tempat yang berbeda dengan audisi gelombang pertama, jumlah pesertanya pun tidak sebanyak audisi gelombang pertama.

\section{Panggung Fesyen IP-SF 2018}

Berakhirnya audisi model yang diselenggarakan dalam dua gelombang, mengarahkan para peserta untuk melanjutkan pada tahap berikutnya yaitu acara IP-SF 2018. Dalam penyelenggaraan IP-SF 2018, dibagi menjadi empat sesi catwalk, pada tanggal 17 dan 24 Februari 2018, serta tanggal 3 dan 10 Maret 2018. IP-SF 2018 diadakan di South Quarter Dome atau SQ Dome yang berlokasi di Cilandak Barat, Jakarta Selatan.

Terbaginya sesi IP-SF 2018, juga membagi peserta model yang terlibat. Pada sesi pertama yang diadakan pada tanggal 17 Februari 2018, penyelenggara hanya memberi kesempatan pada 30 model, kemudian jumlah model yang sama pada 
sesi berikutnya hingga sesi ketiga. Sedangkan pada sesi terakhir atau puncak acara tanggal 10 Maret 2018, penyelenggara memanggil kembali semua peserta audisi sekalipun sudah tampil pada sesi sebelumnya. Terutama untuk peserta yang berasal dari luar Jakarta, penyelenggara memberi waktu khusus untuk tampil pada puncak acara.

Setiap menjelang sesi IP-SF 2018, penyelenggara selalu mengingatkan para peserta untuk datang pukul 08.00 pada hari $\mathrm{H}$ acara. Sekalipun para model tampil pada sore hari, penyelenggara memanfaatkan pagi hari untuk mempersiapkan para model. Dimulai dengan adanya gladi bersih, para model memiliki satu ruang berlatih yang dipandu oleh Oditama dengan ketat. Fokus dan serius adalah kata yang sering diserukan Oditama saat melatih para model. Selain memerlukan keseriusan yang tinggi, peserta yang kurang fokus dan salah dalam berjalannya akan diminta untuk mengulang kembali dari belakang panggung.

Dalam obrolan singkat dengan para peserta, penulis mendapati mayoritas dari para peserta belum pernah memiliki pengalaman bermodel sebelumnya, termasuk penulis sendiri. Belum adanya pengalaman tersebut membuat gladi bersih menghabiskan banyak waktu dan tenaga. Para model saat gladi bersih juga menggunakan sepatu dengan hak tinggi yang nantinya dikenakan saat tampil. Sepatu dengan hak tinggi tentu memberi kesan cantik, namun menyiksa kaki perempuan gemuk dalam menopang berat tubuhnya. Disamping rasa sakit yang dirasakan, niat para model untuk tampil mengalahkan rasa sakit di bagian kaki.

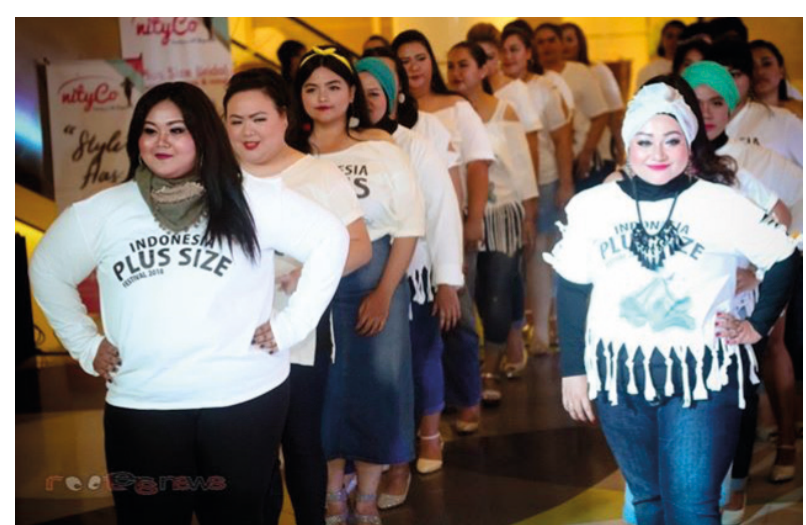

Gambar 5. Model bertubuh gemuk dalam puncak acara IP-SF 2018. (Sumber: www.instagram.com/roostersnews; diakses pada tanggal 19 April 2018)
Gladi bersih diakhiri pada jam makan siang, dimana para model beristirahat serta mempersiapkan diri untuk tampil. Persiapan meliputi rias wajah dan juga menata rambut masing-masing model. Aktivitas persiapan para model dilakukan di satu ruangan khusus beralas karpet dan disediakan kaca untuk mematut diri. Selain aktivitas rias wajah dan tata rambut, berbagai aktivitas menarik lainnya, salah satunya adanya aktivitas jual beli. Barang yang perjual belikan juga beragam, seperti keperluan permodelan; aksesoris, bulu mata palsu, hingga kuku palsu. Barang yang dikhususkan untuk perempuan gemuk juga ada yang menjual di ruang persiapan tersebut, seperti pakaian dalam berupa bra dan celana dalam serta pakaian renang. Menjual pakaian dalam khusus untuk perempuan gemuk, tentu menyasar pada target pasar yang tepat, dimana pada saat itu berkumpul para perempuan gemuk di satu tempat.

Setelah para model bersiap dengan rias wajah dan tata rambutnya, salah satu panitia menginformasikan kepada kelompok perempuan gemuk yang tampil khusus pada hari tersebut untuk memilih pakaian yang disediakan oleh desainer pakaian bagi perempuan gemuk. Pemilihan pakaian dibebaskan pada masing-masing perempuan, asalkan diri sendiri merasa nyaman dengan pakaian yang dipilihnya.

Selepas penampilan busana dari desainer, masuk pada acara berikutnya yaitu penampilan busana untuk berolahraga yang ditampilkan oleh model senior. Selain permodelan, penampilan vokal juga ditampilkan oleh perempuan gemuk yang memiliki bakat di bidang tarik suara. Pada puncak acara, IP-SF 2018 menampilkan seluruh peserta audisi dengan pakaian putih bertuliskan IP-SF serta bawahan berbahan denim. Pakaian putih dengan bebas dikreasikan oleh para model sendiri, bawahanpun juga beragam, ada yang mengenakan celana panjang ataupun pendek serta rok. Penampilan para model pada puncak acara dapat dilihat pada gambar 5 .

IP-SF 2018 merupakan satu acara yang komplek dengan aktivitas perempuan gemuk, karena segala aspeknya melibatkan perempuan gemuk. IP-SF 2018 menjadi ajang pembuktian bahwa perempuan gemuk dapat menunjukkan 
eksistensinya dalam bidang fesyen. Hanya saja, antusias masyarakat masih belum begitu terlihat dalam acara ini, terbukti dengan jumlah penonton acara yang masih didominasi kerabat dekat para model sendiri. Di sisi lain, lokasi acara yang tidak begitu ramai pengunjung, juga menjadi satu faktor tersendiri yang menyebabkan jumlah penonton yang tidak terhitung membludak. Meskipun tidak begitu ramai penonton, para model tetap menampilkan dirinya semaksimal mungkin.

\section{Ririe Bogar dibalik IP-SF 2018}

Berjalannya acara IP-SF 2018 merupakan satu bentuk dedikasi yang dilakukan Ririe Bogar sebagai sosok agen perubahan bagi perempuan gemuk. Sebagai pemrakarsa, Ririe Bogar mengajak tim yang memiliki visi serupa dalam menjalankan acara permodelan fesyen untuk perempuan gemuk. Untuk mendalami sosok Ririe Bogar dalam mengadakan acara IP-SF 2018, penulis melakukan wawancara mendalam pada tanggal 21 Februari 2018.

Penulis pertama kali mengetahui sosok Ririe Bogar dari buku pertama yang ditulisnya dengan judul "Cantik itu Ejaannya Bukan K.U.R.U.S" (Bogar, 2015). Judul buku yang sekaligus menjadi kalimat kampanye bagi Ririe Bogar, tentu tidak terlepas dari visinya untuk merubah pandangan masyarakat pada perempuan gemuk. Buku tersebut sendiri juga berisi kalimat motivasi yang ditujukan bagi perempuan yang tidak kurus. Buku kumpulan motivasi itu didesain dengan tata letak yang menarik. Sosok Ririe Bogar dan bukunya dapat dilihat pada gambar 6 .

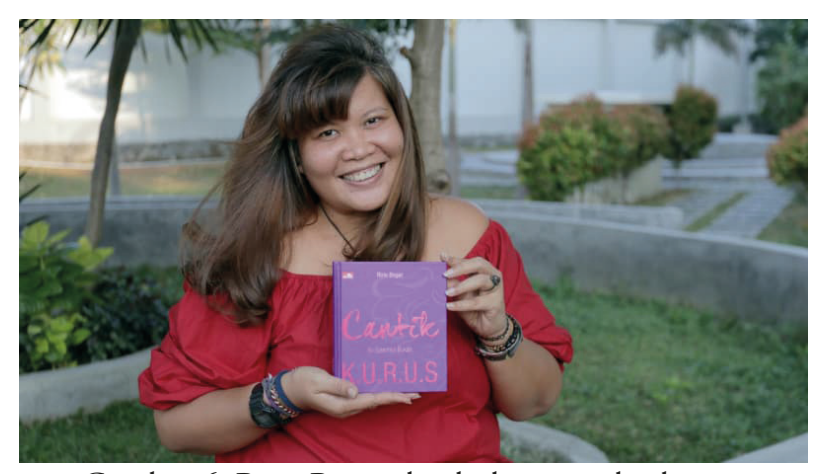

Gambar 6. Ririe Bogar dan buku yang ditulisnya. (Sumber: https://kumparan.com; diakses pada tanggal 9 April 2018)
Ririe Bogar mengawali aktivitas sosialnya setelah mengikuti Miss Impian 2005, sebuah ajang pencarian bakat yang ditayangkan di Indosiar, salah satu saluran TV swasta di Indonesia. Kemudian pada tahun 2007, Ririe Bogar mengadakan acara serupa dengan tajuk Miss Big Indonesia. Ririe Bogar menyebutkan bahwa alasannya mengadakan acara tersebut dikarenakan kejengkelannya pada Puteri Indonesia. Disebutkan bahwa Puteri Indonesia selalu mencantumkan kriteria berat badan dan tinggi badan yang dianggap proporsional, bahkan Ririe Bogar menyebutkan "sebaiknya dituliskan Puteri Indonesia, dalam kurung yang langsing aja"(Bogar, 2018).

Miss Big Indonesia telah diselenggarakan Ririe Bogar sebanyak tiga kali, yaitu pada tahun 2007, 2010, dan terakhir pada tahun 2014. Penyelenggaraan Miss Big Indonesia juga bukan merupakan hal yang mudah, bahkan Ririe Bogar sempat kesulitan mendapatkan sponsor bagi acaranya. Salah satu produk kecantikan, menyebut enggan mensponsori Miss Big Indonesia dikarenakan takut citranya akan produk menurun. Hal tersebut tidak begitu saja mematahkan semangat Ririe Bogar dalam mengadakan Miss Big Indonesia. Ririe Bogar bahkan menjual mobilnya untuk terus mengadakan acara Miss Big Indonesia.

Jika Miss Big Indonesia perlu banyak modal diri seperti pemilihan Puteri Indonesia, berbeda dengan IP-SF 2018. Ririe Bogar menyebutkan bahwa IP-SF 2018 diturunkan standar penilaiannya supaya makin banyak perempuan gemuk yang dapat terlibat. Peserta IP-SF 2018 sekedar perlu melatih dirinya untuk berjalan di catwalk dan memeragakan busana seperti yang dapat dilihat

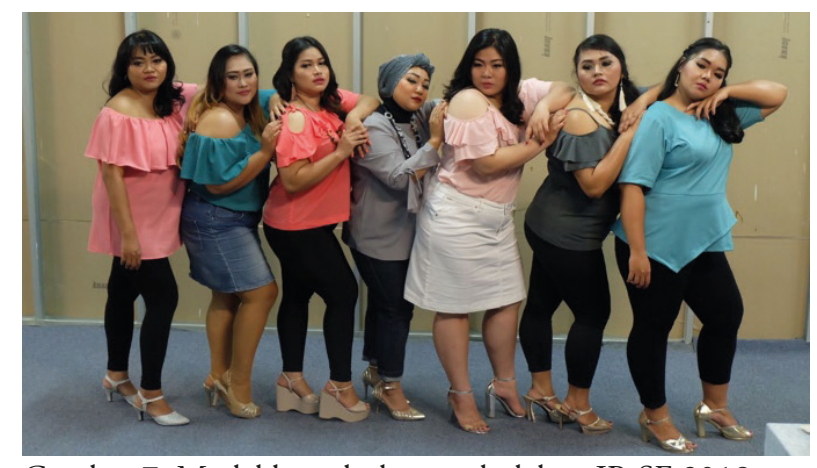

Gambar 7. Model bertubuh gemuk dalam IP-SF 2018 saat memperagakan pakaian karya desainer. (Sumber: Whatsapp Group IP-SF 2018; diakses pada tanggal 1 Juli 2018) 
pada gambar 7, meskipun pada prakteknya tidak semudah itu. Ririe Bogar dan timnya tetap memberikan penilaian psikologis seperti yang dilakukan pada audisi sebelumnya. Salah satu alasan yang mendasari Ririe Bogar mengadakan IP-SF 2018 adalah minat perempuan gemuk yang lebih banyak pada fesyen dan tata rias wajah.

\section{Simpulan}

IP-SF 2018 menunjukkan bahwa fesyen tidak hanya mengakomodasi perempuan dengan tubuh ideal, tetapi juga yang bertubuh gemuk. Perempuan gemuk sebagai model makin banyak dibutuhkan seiring dengan makin banyaknya produsen pakaian yang memproduksi pakaian siap pakai bagi perempuan gemuk. Perubahan yang terjadi juga tidak terlepas dari agen perubahan. Agen perubahan mampu membuat masyarakat menyadari bahwa stigma negatif yang melekat pada diri perempuan gemuk tidak sepenuhnya benar.

\section{Ucapan Terima Kasih}

Terima kasih diucapkan sebanyak-banyaknya kepada (1) Prof M Dwi Marianto, MFA, PhD; (2) Dr Sarah Rum Handayani Pinta, MHum yang membimbing penulisan penelitian; dan (3) Dr Rr Paramitha Dyah F, MHum; (4) Wiwik Sushartami, MA, PhD selaku penguji pada tesis penulis sehingga mendapatkan banyak masukan berguna dalam tulisan ini.

\section{Kepustakaan}

Arumingtyas, B. B. (2018). Pakaian Siap Pakai bagi Perempuan Gemuk: Kajian Desain Kritis.
Universitas Gadjah Mada.

Bogar, R. (2015). Cantik Itu Ejaannya Bukan K.U.R.U.S. Jakarta: Elex Media Komputindo.

Bogar, R. (2018). Wawancara Pribadi Penulis dengan Ririe Bogar. Jakarta.

Gailey, J. A. (2014). The hyper(in)visible fat woman: Weight and gender discourse in contemporary society. The Hyper(in)visible Fat Woman: Weight and Gender Discourse in Contemporary Society. https://doi.org/10.1057/9781137407177

Goenawan, F. (2007). Ekonomi Politik Iklan di Indonesia Terhadap Konsep Kecantikan. Scriptura, 1(1), 14-24. https://doi.org/https:// doi.org/10.9744/scriptura.1.1.

Kahija, Y. La. (2017). Penelitian Fenomenologis (I). Yogyakarta: PT Kanisius.

Kaiser, S. B. (2012). Fashion and Cultural: Cultural Studies, Fashion Studies. In Fashion and Clutural Studies (1st ed.). London: Berg Publisher.

Marianto, M. D. (2017). Art \& Life Force in a Quantum Perspective. Yogyakarta: Scritto Books Publisher.

Prabu, W. N. D. (2017). Imaji Pop Surealisme: Figur Gendut dalam Lukisan. Journal of Urban Society's Arts, 4(1), 36-48.

Tampubolon, A., \& Darmawan, C. (2016). Fashion Budaya Nasional dalam Konteks Wawasan Kebangsaan: Studi Kasus pada Jember Fashion carnaval. Journal of Urban Society's Arts, 3(1), $19-26$.

WHO. (2017). Obesity. Retrieved November 20, 2017, from http://www.who.int/mediacentre/ factsheets/fs311/en/

Wolf, N. (1990). Mitos Kecantikan: Kala Kecantikan Menindas Perempuan. (A. Swastika, Ed.) (Terjemahan). Yogyakarta: Niagara. 